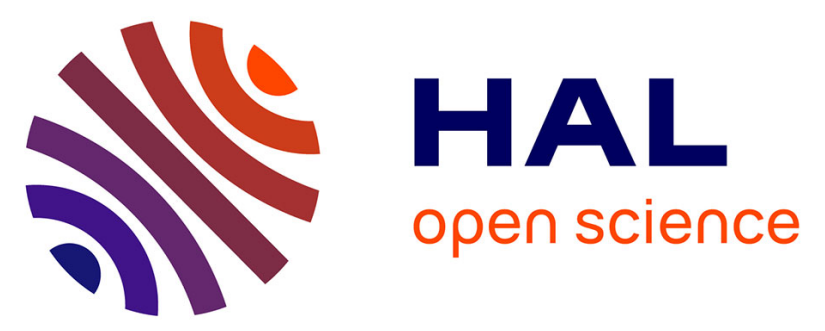

\title{
Trends of labile trace metals in tropical urban water under highly contrasted weather conditions
}

\author{
J.D. Villanueva, Philippe Le Coustumer, A Denis, A Abuyan, Frederic \\ Huneau, Mikael Motelica-Heino, Nicolas Peyraube, Hélène Celle-Jeanton, \\ T.R. Perez, M.V.O Espaldon
}

\section{To cite this version:}

J.D. Villanueva, Philippe Le Coustumer, A Denis, A Abuyan, Frederic Huneau, et al.. Trends of labile trace metals in tropical urban water under highly contrasted weather conditions. Environmental Science and Pollution Research, 2015, 22 (18), pp.13842-13857. 10.1007/s11356-015-4835-6 . insu01165174

\section{HAL Id: insu-01165174 \\ https://hal-insu.archives-ouvertes.fr/insu-01165174}

Submitted on 18 Jun 2015

HAL is a multi-disciplinary open access archive for the deposit and dissemination of scientific research documents, whether they are published or not. The documents may come from teaching and research institutions in France or abroad, or from public or private research centers.
L'archive ouverte pluridisciplinaire HAL, est destinée au dépôt et à la diffusion de documents scientifiques de niveau recherche, publiés ou non, émanant des établissements d'enseignement et de recherche français ou étrangers, des laboratoires publics ou privés. 


\section{Trends of labile trace metals in tropical urban water under highly contrasted weather conditions}

J. D. Villanueva ${ }^{1,2,3}$, P. Le Coustumer ${ }^{1}$, A. Denis ${ }^{2}$, R. Abuyan ${ }^{4}$, F. Huneau ${ }^{5,6}$, M. Motelica-Heino $^{7}$, N. Peyraube ${ }^{2}$, H. Celle-Jeanton ${ }^{8,9,10}$, T.R. Perez ${ }^{11}$, M.V.O. Espaldon ${ }^{3}$

${ }^{1}$ Université de Bordeaux, EA 4592 Géoressources\& Environnement, ENSEGID, 1 allée F. Daguin, F-33607 Pessac, France

${ }^{2}$ Université de Bordeaux, I2M-GCE, B18 Avenue des facultés, 33405 Talence, France

${ }^{3}$ University of the Philippines, Los Baños, School of Science and Environmental Management, College, Laguna 4031, Philippines

${ }^{4}$ Southern Luzon State University, Mathematics Department, Lucban 4328, Quezon, Philippines

${ }^{5}$ Université de Corse Pascal Paoli, Faculté des Sciences et Techniques, Laboratoire d'Hydrogéologie, Campus Grimaldi, BP 52, F-20250 Corte, France

${ }^{6}$ CNRS, UMR 6134, SPE, F-20250 Corte, France

${ }^{7}$ Université d'Orléans, UMR CNRS 7327, ISTO, Campus Géosciences, 1A rue de la Férollerie, F-45071 Orléans Cedex 2, France

${ }^{8}$ Clermont Université, Université Blaise Pascal, Laboratoire Magmas et Volcans, BP 10448, 63038 Clermont-Ferrand, France

${ }^{9}$ CNRS, UMR 6524, LMV, 63038 Clermont-Ferrand, France

${ }^{10}$ IRD, R 163, LMV, 63038 Clermont-Ferrand, France

${ }^{11}$ Ateneo de Manila University, Department of Environmental Science, Loyola Height, Quezon City 1108, Philippines

Contact author: Philippe Le Coustumer

E-mail: plc@lnet.fr 


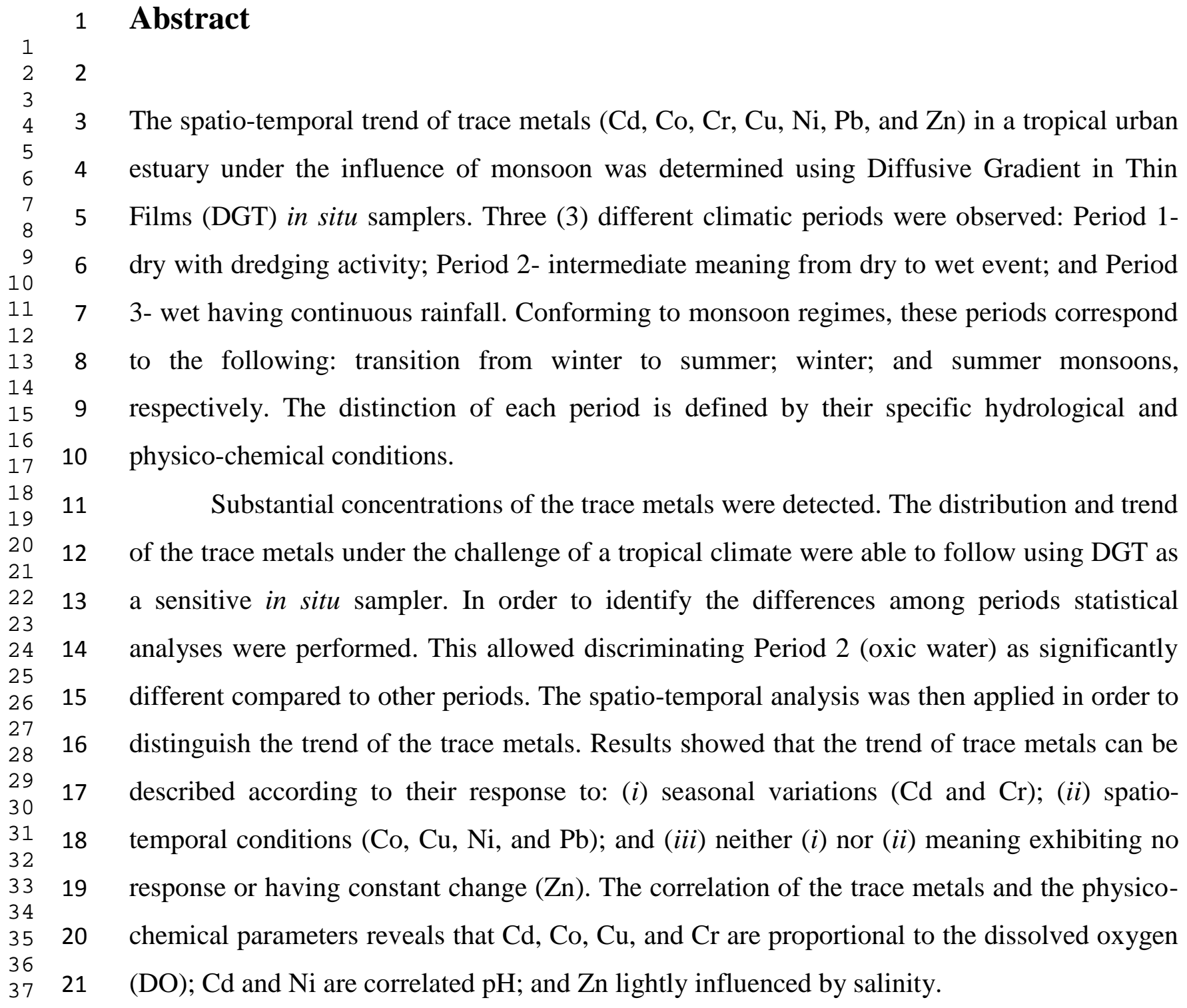

23 Keywords: labile trace metal, urban water, tropical climate, monsoon, statistics, DGT 


\section{Introduction}

Tropical waters are dynamic environments. There are loads of factors that influence these aqueous systems such as different activities like estuarine mixing, tidal currents, sediment remobilization, and fine grain sediments transport (Kuehl et al. 1996 and Breckel et al. 2005). Moreover, seasonal timescales (e.g. monsoonal climate) induced by precipitation and other weather conditions affect the hydrological cycle (Chakraborty et al. 2010). Under monsoon regime, seasonal differences are pronounced and mostly distinguished by the absence and presence of precipitation (Takahashi 2013). This type of climate is challenging as uptight circumstances are at hand. Alterations in the hydro-climatic scheme can be experienced (Hestir et al. 2013). For instance, incident of disruptions of the ocean-atmosphere interactions can occur (Shirasago-Germán et al. 2015). These are principal sources of disturbance in water basins.

Nowadays, the increasing apprehensions on the tropical waters not only rest in the hydro-climatic conditions but on the water quality as well. Particular interests are on the trace metals in terms of contamination and environmental risks. These are important environmental issues. Studies aim to know the possible effects of metals in urban runoff (Herngren et al. 2005) and pollution discharges (Ki et al. 2011) in the aquatic system and the biota.

Trace metals are ubiquitous, easily transported to water (Chen et al. 2014). The behavior of the trace metals in estuaries varies greatly due to environmental factors like hydrodynamic residence time, mixing patterns of transport processes and reservoir management (Hatje et al. 2003; Masson et al. 2006; Masson et al. 2011). Another factor is the water chemistry that changes from freshwater to saltwater that influences their occurrence (Jian and Wen 2009). The trend differs according to seasonal changes and suspended sediments concentrations (Park et al. 2011). Precipitation, for example, can play as an atmospheric wash out that delivers trace metals to aquatic ecosystem through deposition mechanism (Özsoy and Örnektekin 2009). To deduce, in tropical waters, trace metals can be perceived as active components in the environment and, at the same time, reactive elements in the aqueous systems. These directed towards serious intentions and efforts to assess the water quality of tropical waters including estuaries specially those who are situated in highly urbanized zones.

Labile trace metals are vital in examining the state of these tropical waters. This fraction can eventually help in assessing toxicity and associated risks (Pinhero and Domingo 
1 2005). However, measuring these specific forms requires collecting voluminous water which

2 is tedious and time consuming (Graveline et al. 2010). Alternatively, in situ sampling 3 technique can be employed. It can provide data over longer periods of time and reduces some 4 of the drawbacks of grab sampling (INAP 2002).

For this reason, Diffusive Gradient in Thin-Films (DGT) is used to monitor trace metals in aquatic system. This device has the ability to perform measurements (Davison and Zhang 1999) at a lower cost. It is an in situ method that can sequester labile fractions (Naylor et al. 2004; Li et al. 2005; Søndergaard et al. 2008; Vystavna et al. 2012a and 2012b) even at very low concentrations (Zhang et al. 1995). This technique for measuring trace metal and monitoring water bodies is long-established and delivers valuable results with lesser sampling activities needed (Alfaro-De la Torre et al. 2000; Clarisse et al. 2009; Gao et al. 2010; Wu et al. 2011; Villanueva et al. 2013).

The purpose of this research is mainly to determine the labile trace metals response to differing climatic and physico-chemical conditions in a dynamic estuarine system in a tropical setting. The Pasig River in Manila, Philippines was chosen due to the distinct water dynamics (as this is an estuary in nature) and climate background. The seasonal changes are pronounced and contrasting because of the influence of the monsoon and precipitation anomalies over tropical regions (Villafuerte et al. 2014). These variations are caused by surface reverse directions and local winds (Han et al. 2009).

This study would like establish the trend of labile trace metals in a tropical water facing monsoon seasons. The focus is on determining the importance of the episodic events on the trace metal loads and availability of the labile fractions in highly industrialized and urbanized tropical water. The specific objectives are: $(1)$ to describe the trend of the labile trace metal $(\mathrm{Cd}, \mathrm{Co}, \mathrm{Cr}, \mathrm{Cu}, \mathrm{Ni}, \mathrm{Pb}$ and $\mathrm{Zn})$; (2) to distinguish the effect of seasonal changes under monsoon regime in a tropical aquatic system in terms of hydrochemistry and physicochemical conditions; and (3) to determine which among labile trace metals are more vulnerable to spatio-temporal changes.

Three (3) local seasons were considered: dry, transition from dry to wet (intermediate), and wet. The difference in the seasonal pattern can lead to a premise that the trace metals trend will also be significantly distinct from each period. To assess if this premise holds, statistics were performed. Hydrochemistry and physical conditions were utilized as parameters. Spatio-temporal analysis was applied to better explain the labile trace metal trends. 


\section{Materials and Methods}

\section{Site description}

The Pasig River is an estuary of about $27 \mathrm{~km}$ long and approximately $80 \mathrm{~m}$ wide. The catchment is composed of 4 main tributaries (San Juan River, Marikina River, Napindan River, and Pateros-Taguig River) and 43 minor tributaries. It is located in the heart of Manila, Philippines (Fig. 1) and connects Laguna Lake (east), the biggest freshwater lake in the Philippines and the Manila Bay (west). The salinity intrusion from the bay can reach towards the whole stretch of the Pasig River to the mouth of the lake.

Manila Bay mostly serves as a shipyard. Laguna Lake has many functions that include aquaculture and fishery (open fishing), irrigation, power generation and navigational lane. This site is situated in a highly industrialized and urbanized area with a rough estimated population of $11,500,000$ plus fluxes of informal settlers which are about $30 \%$ of the total Metro Manila region (Aiga and Umenai 2002). This water body normally receives non point sources of effluent wastes of different forms. Poor solid waste management is in addition a challenge in the area.

\section{Sampling Design}

The sampling design followed seasonal patterns in the study area. Sampling campaigns were conducted that corresponded to: Period 1- dry with an ongoing dredging activity (April to May 2010); Period 2- intermediate: from dry to wet season (January 2011); and Period 3- wet season (May to June 2011). The rainfall behavior during the sampling campaigns is presented in Table 1. Following these differing precipitation rates, the hydrology of the Pasig catchment varied strongly in between periods.

Four sites (Fig. 1) were chosen representing the upstream (point 1: mouth of the Manila Bay), midstream (points 2 and 3 which are near the San Juan and Marikina River, respectively); and downstream (point 4: mouth of the Laguna Lake), with an approximate distance of $7 \mathrm{~km}$ in each site. Point 4 signals freshwater interference in the river. In each site, DGT in duplicates were fully immersed for 18 days. DGT field blank was provided per sampling campaign. Strict protocols of DGT deployment (Villanueva 2013) were followed for all sampling campaigns. Immediately, after the retrieval, the DGT probes were rinsed with de- 
1 ionized water and placed in pre-cleaned properly marked resealable plastic containers. A

2 cooling compartment was prepared to transport the probes directly to the laboratory. DGTs

3 were put in the refrigerator before the extraction of the trace metals.

During each sampling campaign, physical parameters such as dissolved oxygen (DO), water temperature, salinity, conductivity and $\mathrm{pH}$ were measured in situ using YSI $6600 \mathrm{~V} 2$ data probe at a depth of approximately $1 \mathrm{~m}$ below the water surface. The range of values is presented in Table 2. According to the study of Materum 2010 and Villanueva 2013, total organic carbon (TOC) of the Pasig River ranged from 3.4 to $4.5 \mathrm{mg} / \mathrm{L}$ during May 2010 and 3.5 to $7.4 \mathrm{mg} / \mathrm{L}$ for January 2011 .

\section{Determination of trace metals concentration}

Standard solution Chelex-100 DGT probes were purchased from DGT Research Ltd, Lancaster, UK. DGT field blanks were extracted and analyzed using the same procedure for the DGTs immersed in the water. Laboratory procedural blanks were prepared. The detection limits were determined following the already established procedure (Pettke et al.2012). In the laboratory, the membrane filter and the diffusive gel were carefully removed from the piston using Teflon tweezers. The gel was separated and placed into a clean polypropylene micro centrifuge tube. $1 \mathrm{ml}$ of $1 \mathrm{M}$ of $\mathrm{HNO}_{3}$ (Fisher Scientific Analar grade) was added. After 24 hours, dilution was performed. The trace metals were determined using inductively coupled plasma-mass spectrometry (Thermo Scientific*ELEMENT2*ICP-MS). From the elution solution, the accumulated mass of the trace metals then the concentrations were calculated. The detailed laboratory procedures (Dunn et al. 2007; Aung et al. 2008) and calculations (DGT Research 2002) can be found elsewhere (INAP 2002).

\section{Trend Analysis approach}

Two (2) approaches were applied: statistical and spatio-temporal analyses. The statistical analyses permit discriminating the periodical differences. This can also describe the relationship in between parameters: hydro and physico-chemical variables and trace metal concentrations. The spatio-temporal analysis is valuable in determining the trends of the trace metals by evaluating their response in each seasonal or temporal variation and inspecting the increase or decrease of the concentration in a spatial sense. 


\section{1}

Statistical tests

2

3 In order to determine the significance among periods using the concentrations of the pool of 4 labile metals, series of statistical tests were utilized. Student $t$-test was considered as it is 5 appropriate for small data sets (population samples). This test is normally applied for the 6 comparison of two means (Fritz and Berger 2015). Hence, allowing comparing a period to 7 another using the concentration of the trace metals as data sets. Two-tailed $t$-test was 8 employed pairing each period's data sets (trace metals concentrations). The significance level 9 was determined using the value $\alpha=0.05$. To validate and illustrate the difference, hierarchical 10 cluster analysis was performed.

Correlation analysis was applied to determine the potential relationship of the physicochemical parameters (DO, water temperature, $\mathrm{pH}$, salinity, and conductivity) and how each can influence one another. Subsequently, the correlation of the physico-chemical parameters to the labile trace metals was carried out.

\section{Spatio-temporal analysis}

The spatio-temporal analysis can discriminate the trend of each labile trace metals by examining the tendency of concentrations. The variation can be sorted according to the inclination of each trace metal. This approach aids in determining which trace metals are susceptible to: (i) seasonal or climatic conditions changes; (ii) spatial or local variations; (iii) both spatial and seasonal disparities; and (iv) neither spatial nor local situation (absence of changes). The first can be related to temporal events, while, the second can be associated to anthropogenic activities and/or instantaneous contamination. The last can be described as having a conservative or constant trend. 


\section{Results}

\section{Environmental background and Physico-chemical parameters}

The physico-chemical characteristics of the water were recorded during each sampling period (Table 2). Period 1 combines two (2) episodic events: dry season and dredging activity. The area experienced shortage on rainfall. Periods 2 and 3, on the other hand, both experienced pronounced rainfall $(\sim 79 \mathrm{~mm})$. Period 2 showed the lowest record for water temperature, salinity, and conductivity. This period has the highest DO level. The periods were best described by the DO as the oxygen levels greatly varied through periods. DO range from 0.45 to $1.05 \mathrm{mg} / \mathrm{L}$ on Period $1 ; 5.9$ to $8.2 \mathrm{mg} / \mathrm{L}$ on Period 2; and 1.55 to $2.26 \mathrm{mg} / \mathrm{L}$ on Period 3 . Only Period 2 passed the Department Administrative Order (DAO 34) of the Philippine government. The DO requirement is $>5 \mathrm{mg} / \mathrm{L}$. The salinity was pronounced on Period $3(0.39$ to $8.44 \mathrm{psu}$ ) which also indicated water mixing. In Period 2, salinity was almost constant along the Pasig River stretch. Compared to DO, salinity and conductivity, pH did not exhibit strong variations.

\section{Labile Trace Metals in the Pasig River}

The general trend observed was that most of labile trace metals concentrations increased during Period 2 then decreased during Period 3 (Fig. 2 and Table 3). However, throughout the period, Zn seemed stable. During Period 1, the only DGT-trace metals (at maximum) found at the river end is Ni located near the mouth of the bay (Point 1). Minimum Ni was detected at the confluence of San Juan River (Point 2) while Co has the least at the mouth of the bay (Point 1). Maximum concentrations were mostly near the confluence of San Juan River (Point 2: $\mathrm{Cr}, \mathrm{Cd}$ and $\mathrm{Pb}$ ) and convergence of Marikina River (Point 3: $\mathrm{Co}, \mathrm{Cu}$ and $\mathrm{Zn}$ ).

The minimum concentrations of $\mathrm{Cr}, \mathrm{Cu}, \mathrm{Zn}, \mathrm{Cd}$ and $\mathrm{Pb}$ were found near the mouth of the lake area (Point 4). In this period, at the river ends (Points 1 and 4), lower values of $\mathrm{Cr}$, $\mathrm{Co}, \mathrm{Cu}, \mathrm{Cd}$ and $\mathrm{Pb}$ were found. In contrast, $\mathrm{Ni}$ has the lower values in the midstream (Points 2 and 3). Zn concentration spatially varies. In Period 2, minimum value of $\mathrm{Pb}$ is found near the mouth of the bay (Point 1); $\mathrm{Cr}, \mathrm{Cu}$ and $\mathrm{Zn}$ were at the confluence of San Juan River (Point 2); Co and Ni near Marikina River area (Point 3); and Cd near the mouth of the lake (Point 4). Maximum values of $\mathrm{Cr}, \mathrm{Cu}, \mathrm{Zn}$ and $\mathrm{Cd}$ were found near the mouth of the bay (Point 1), while, 
$1 \mathrm{Co}, \mathrm{Ni}$ and $\mathrm{Pb}$ at the mouth of the lake (Point 4). At this period, the maximum values are all 2 found at the river ends (Point1 and 4).

3

4

5

6

For Period 3, $\mathrm{Cu}$ has the least concentration at the mouth of the bay (Point 1). Maximum values were traced in the sampling points except near the lake: $\mathrm{Cr}$ and $\mathrm{Cd}$ were found near the bay area; at the confluence of San Juan River (Point 2: Co, $\mathrm{Zn}$ and Pb); and near at the Marikina River (Point 3: $\mathrm{Ni}$ and $\mathrm{Cu}$ ). Most of the minimum values were at the mouth of the lake (Point 4: Cr, $\mathrm{Co}, \mathrm{Ni}, \mathrm{Zn}, \mathrm{Cd}$ and $\mathrm{Pb}$ ).

\section{Labile trace metal concentrations and statistical difference among periods}

The Student $t$-test was performed by pairing the data (Period 1 vs. Period 2; Period 1 vs. Period 3; and Period 2 vs. Period 3). The result of the statistical test is shown in Table 5. Significant difference were found in between Period 1 and $2(\alpha=0.05 ; p=0.022)$ and Period 2 and $3(\alpha=0.05 ; p=0.016)$ but not for Period 1 and Period $3(\alpha=0.05 ; p=0.437)$.

To illustrate, the hierarchical cluster analysis was performed generating a dendrogam (Fig. 4a). The dissimilarity between the periods agreed to the statistical analysis performed where Period 2 was isolated (left). Observations on the spatial patterns of Periods 1 and 3 showed that for both periods, most of the maximum concentrations of each trace element are found at the midstream (Points 2 or 3), while, most of the minimum concentrations of each trace element are at the endstream (Points 1 or 4). Another dendrogram (Fig. 4b) was generated considering only Periods 1 and 3. The result demonstrated that Period 1 is grouped together, whereas, Period 3 is clustered into 3 groups.

\section{Correlation among parameters}

The correlation among physico-chemical parameters is shown in Table 6. DO has an inverse relationship to other physico-chemical parameters. This inverse relationship is more pronounced with respect to the water temperature $(\alpha=0.05 ; p=-0.91)$. In terms of salinity, Periods 1 and 3 showed evident water mixing. Although, the salinity values are lower in Period 1, water mixing was also observed. There is also a weak confirmation of the inverse relationship of DO to salinity $(\alpha=0.05 ; p=-0.42)$. Water temperature and salinity are positively correlated to conductivity, whereas, DO showed negative correlation. 
Among trace metals (Table 7), Zn demonstrated weak correlation to other trace metals.

2 Direct relationship was present in between the following trace metals: $\mathrm{Co}-\mathrm{Cd}(r=0.80), \mathrm{Co}-\mathrm{Cr}$ 3 (r= 0.77), $\mathrm{Cu}-\mathrm{Cd}(r=0.71), \mathrm{Cu}-\mathrm{Co}(r=0.69), \mathrm{Cu}-\mathrm{Cr}(r=0.92)$, and Ni-Cd $(r=0.75)$. In 4 between the physico-chemical parameters and the trace metals, $\mathrm{DO}$ followed the $\mathrm{Cd}, \mathrm{Co}, \mathrm{Cu}$, 5 and $\mathrm{Cr}$; and $\mathrm{pH}$ is correlated to $\mathrm{Cd}$ and Ni. Potential relationship in between salinity and $\mathrm{Zn}$ 6 was traced.

7 8

\section{Discussion}

\section{Environmental background}

The Philippines is within the regime of monsoon seasons of Southeast Asia (Loo et al. 2014). This type of climate system is dynamic as it is characterized by wet spell having periodic heavy rains and dry spell with seasonal changes driven by the wind directions (Stephens et al. 2008). The active factors coming from the interaction of the oceans and atmosphere could lead to droughts and wet episodes (Buckley et al. 2014). It has significant impacts on the environment including water systems (Cook and Jones 2012; Varis et al. 2012). Monsoon climate dictates the variability of the temperature of the water catchments (Meybeck 2009) and hydrodynamics (Fuchs et al. 2012). It can also affect the quality of the water resource (Wilkerson et al. 2002; Hestir et al. 2013). For these reasons, under this climate regime, it is noteworthy to know how the hydrochemistry of the Pasig River responds.

\section{Monsoonal Climate Regime}

Seasonality of monsoon can be categorized according to months. Cruz et al. 2012 explains that the main monsoon regimes are the Northeast monsoon and the Southwest monsoon. Northeast monsoon or the winter monsoon can be expected on November to March. Southwest monsoon or summer monsoon starts May and ends on September. On October, the transition from Southwest monsoon to Northeast monsoon occurs. Adhering to the monsoon regime, Period 1 fell under the transition from Northeast to Southwest monsoon (in between 
1 winter and summer monsoon); Period 2 experienced Northeast/winter monsoon; and Period 3

2 encountered Southwest/summer monsoon.

3

4

5

6 7

\section{Hydro-physico-chemical variation}

The variation of DO followed by the water mixing express the differences among periods. Through periods there is a shift from almost anoxic to oxic then hypoxic waters. In terms of incidence of water mixing, the trend is as follows: Period 3>Period 1>Period 2. The conductivity follows the trend of the salinity, Period 2 having least values. The water temperature is almost the same for Periods 1; and 3 and lowest during Period 2. For $\mathrm{pH}$, Period 1 was more basic than Period 2 and Period 3 played slightly acid to neutral water.

\section{Spatio-temporal analysis on trace metals}

Period 1 as stated was under a dry weather. Twenty (20) days prior to the sampling campaign, there was only $0.8 \mathrm{~mm}$ of rainfall. A total of $6 \mathrm{~mm}$ of rainfall was accumulated within this sampling period which implied river low flow. At this period, there was an on-going dredging activity. Dredging is an ecological disturbance that can affect the sediment structure (Mackie et al. 2007; Je et al. 2007). Both particulate forms (Nayar et al. 2004) and bioavailability (Lewis et al. 2001) of trace metals in the water column could increase (Cabrita 2014) due to resuspension (Fathollahzadeh et al. 2015). Studies showed that the release of the dissolved trace metals can be attributed to the binding mechanism to the solid phase or on the mechanisms involving sorptive phases (van den Berg et al. 2001). Also the changes in the water chemistry like $\mathrm{pH}$ and ionic strength can affect the release of the dissolved trace metals (i.e. lower $\mathrm{pH}$ increase the solubility of the trace metals).

In wet seasons, atmospheric deposition, surface run-off (Witt et al. 2010), and atmospheric precipitation (Migliavacca et al. 2005; Vuai et al. 2011) contribute to trace metals delivered to the receiving body (Dunn et al. 2007) such as rivers (Aung et al. 2008). Periods 2 and 3 both received almost the same amount of precipitation throughout the sampling campaign. However, twenty days before the sampling activity in Period 3, the accumulated rainfall amount was only $125.2 \mathrm{~mm}$ already, whereas, Period 2 received only $14.4 \mathrm{~mm}$. These periods displayed different hydro-chemical characteristics. The hydrochemical condition illustrates the distinction of this period being least in salinity, water 
1 temperature, and conductivity at the same time highest in DO values. Period 3 has the highest 2 recorded water temperature, salinity, and conductivity. Knowing the hydro-chemical 3 background, the interesting issue is on what can be the response of each of these differing conditions to the labile trace metal concentrations.

\section{Trace metal variation}

The ranges of the trace metal concentrations are summarized in Table 3, while, the variations are presented in Fig. 2. Period 2 is discriminated as significantly different to Periods 1 and 3. In Table 4, the anthropogenic activities surrounding the river with the trace metals concern are identified. To illustrate the distribution of the different labile trace metals per period and site, pie charts were drawn in Fig.3. These pie charts represent relative percentage of the concentrations of trace metals. $\mathrm{Zn}$ has the largest portion during Periods 1 and 3. In Period 2, $\mathrm{Cr}$ has the leading share. The second biggest part among periods is as follows: Period 1: mostly $\mathrm{Cd}$ followed by $\mathrm{Cr}$; Period 2: $\mathrm{Zn}$ followed by $\mathrm{Cu}$; and Period 3: $\mathrm{Cu}$ then $\mathrm{Co}$.

\section{Spatio-temporal variation of trace metals}

As a point of observation, the variation of each trace metals follows three (3) trends. The trace metals can be group according to their response in a spatio-temporal approach. First, the trace metals that exhibited seasonal (temporal) variation or changes of the concentrations differ between periods. Second, trace metals that are sensitive spatially and temporally, indicating variations in each site and in each period (season). Third, a trace metal that is constant through time. Seasonal variation is observed in labile trace metals $\mathrm{Cd}$, and $\mathrm{Cr}$. The spatial and temporal sensitive trace metals are depicted by $\mathrm{Co}$ and $\mathrm{Cu}$ and mainly by $\mathrm{Ni}$ and $\mathrm{Pb}$. Among the trace metals, $\mathrm{Zn}$ has a different trend by appearing constant through time.

\section{Cr and. Zn: The trend and origin}

Significant concentrations of trace metals were detected in the Pasig River in varying amount. There is an interesting aspect in terms of anthropogenic and geogenic origins. In Fig. 3, the largest portions are $\mathrm{Cr}$ and $\mathrm{Zn}$. Among the trace metals, $\mathrm{Cr}$ showed the most considerable trend in between periods. The results showed how the dissolved $\mathrm{Cr}$ in the Pasig River is sensitive to seasonal and hydrochemistry changes. There is a notable point in $\mathrm{Cr}$ being the 
1 highest during Period 2. Table 4 provided probable sources of emissions situated at the 2 riverbank. Cr could also be associated to atmospheric fallout or rainfall and surface runoffs 3 (Neal et al. 1996). During Period 3 series of rainfall served as a wash out of Cr that is why 4 lesser concentration was detected.

As the spatio-temporal analysis revealed, unlike $\mathrm{Cr}, \mathrm{Zn}$ is neither affected by dilution nor the variation of physico-chemical parameters. $\mathrm{Zn}$ is normally abundant in urban water runoff. It is interesting to look at its geogenic origin. The interaction of $\mathrm{Zn}$ with $\mathrm{Cd}$ and the distribution in estuaries can be studied (Audry et al. 2004; Dudka et al. 1994).

The fractionation of $\mathrm{Zn} / \mathrm{Cd}$ can explain the trace element pattern as a response to the geochemical phases. Its concentration ratio changes according to different geochemical phases occurring in geochemical path such as in streams, rivers, estuaries, coastal seas and open oceans (Gerringa et al. 2001). The result of this study showed that $\mathrm{Zn}$ has a significant relationship to $\mathrm{Cd}(r=0.61) . \mathrm{Zn} / \mathrm{Cd}$ ratio can give clear estimates on the relative geochemical behavior (Mazeina et al. 1999) and can trace their sources. The $\mathrm{Zn} / \mathrm{Cd}$ ratio obtained ranges 9.32-11.65 for Period 1; 5.88-8.48 for Period 2; and 502.72-1174.83 for Period 3. The ratio that ranges from 5-10 can be attributed for oceanic waters (Gerringa et al. 2001). In the world record, the ratio 7.5 is said to be carried by riverine suspended sediments to the oceans in dissolved phase (Viers et al. 2009). Higher ratio (>500), like in Period 3 can be traced in ore elements from basaltic, igneous rocks and sediments (Gerringa et al. 2001; Nolting et al. 1999; Gottesman and Kampe 2007). Thus, there is an indication that most of $\mathrm{Zn}$ came from runoff.

\section{Importance of the physico-chemical parameters on the labile trace metals}

Physico-chemical environmental parameters are very essential in explaining the chemical spatial distribution of the trace metals. DO plays an important role which is highly influenced by seasonal changes (Sokolowski et al. 2001). As a main point, DO give inverse relationship to other physico-chemical parameters. This inverse relationship is more distinct with respect to the water temperature followed by conductivity. There is a weak proportional relationship in between DO and salinity. Although, the results confirmed the direct relationship in between conductivity and salinity, two (2) tendencies were noticed. Period 1 showed higher slopes than Period 3. Although salinity is lesser in Period 1, conductivity is higher. $\mathrm{pH}$ displayed weak inverse correlation to salinity and conductivity. 
Positive correlations $(r>0.60)$ in between most of the trace metals were observed.

2 Weak correlations $(r<0.50)$ are found in between $\mathrm{Cd}-\mathrm{Co}$, Ni-Co-, Ni-Cr, Ni-Cu. Zn portrayed

3 no correlation with other trace metals. The relationships of the concentrations of physico4 chemical parameters and labile trace metals among periods are presented in Fig. 5 and Table 57

DO. Pasig River showed that trace metals $(\mathrm{Cd}, \mathrm{Co}, \mathrm{Cr}, \mathrm{Cu}$, and $\mathrm{Pb})$ are directly proportional to DO except for $\mathrm{Ni}$ and $\mathrm{Zn}$. Oxic water favors dissolved metals (Buffle and van Leeuwen 1993). The oxic levels of each period are distinguished accordingly: Period 1 is near anoxia; Period 2 shows oxic water; and Period 3 is hypoxic water (Table 2). Using the abovementioned parameters and their relationships to the dissolved oxygen, Period 2 should have the highest trace metal concentration followed by Period 3. Period 1 will give the least concentrations. This is true for the actual case of Period 2 only but not for Periods 1 and 3 . During Period 3, continuous rainfall led to lesser concentrations of the trace metals. Fig. 5 shows that from hypoxic towards oxic level the concentrations of most of the trace metals $(\mathrm{Cd}, \mathrm{Co}, \mathrm{Cr}, \mathrm{Cu}, \mathrm{Ni}$, and $\mathrm{Pb})$ increased. In oxic water, trace metals are mostly driven by sorption reaction; while, trace metals are controlled by sulfide precipitation in anoxic water (Buffle and van Leeuwen 1992). Sulfides are strong reducing agents. Low concentration of trace metals in the anoxic water is due to metal sulfide precipitation (Zwolsman and Van Eck 1993).

pH. Water $\mathrm{pH}$ influences the evolution of the concentration of $\mathrm{Cd}$ and $\mathrm{Ni}$. The $\mathrm{pH}$ of the Pasig River is as follows: Period 1- alkaline water; Period 2 neutral water; and Period 3near acidic and neutral water. Following the trace metal and $\mathrm{pH}$ relationship, Period 1 should have the highest concentration, while, Period 3 the least. This is true for the case for Period 3. However, Period 1 ranked the second in terms of labile trace metal concentration even if the water is alkaline. Period 2 is in the first order because of sorption. In Fig. 5, it presents that the concentrations of the trace metals are lower at $\mathrm{pH} \sim 7$ then there is increase of concentrations after the neutral level until ph 7.5. The trace metals distribution is affected by the $\mathrm{pH}$ through acid-base reaction (vanLoon and Duffy 2000). Trace metals sorption has proportional relationship with increasing $\mathrm{pH}$ (Munk et al. 2002). The adsorption of metal cations are more likely to happen when $\mathrm{pH}$ increases at the water column, as the latter increases the particle surface negative charge (Gurumurthy et al. 2013). This can also mean that desorption can be experienced predominantly in the acidic water. Water at high $\mathrm{pH}$ promotes insolubility of the trace metals. 
Salinity and Conductivity. Most of the dissolved trace metals in Periods 1 and 3 have

2 the least concentration near the lake. These periods showed decreasing salinity and

3 conductivity from the bay to the lake. Flocculation of trace metals can be experienced in the 4 area where the lowest salinity was found (Gerringa et al. 2001; Biati et al. 2010). This 5 observation explains why least trace metal concentrations were found during this period at the 6 mouth of Laguna Lake (except for $\mathrm{Cu}$ and $\mathrm{Pb}, r=0.47$ ). $\mathrm{Zn}$ has consistent trend having the 7 least concentration near the bay. $\mathrm{Zn}$ is mainly influenced by salinity (Boughriet et al. 1992). 8 In this study a probable relationship between $\mathrm{Zn}$ and salinity is observed $(r=0.53)$. Like 9 salinity, most of the trace elements have inverse proportion to conductivity. Negative correlations are mostly found for $\mathrm{Co}, \mathrm{Cr}$, and $\mathrm{Cu}$.

\section{Water Quality Threshold}

The Pasig River is a highly urbanized water resource. Several industries and companies surround this river. Table 4 shows potential industrial sources of metals. Philippines would like to comply with the United Nation's AGENDA 21 on the protection of the quality, supply and potential source of water. In the past, Pasig River is an important water source for domestic consumptions of the local inhabitants. Progressively, water quality degradation sank in, manifested by high turbidity and foul smell. Rehabilitation programs are in place to bring back Pasig River to its previous state. Therefore, the concern on the state of the water quality is important.

If the occurrence of the trace metals in drinking water set by the World Health Organization (WHO 2008) will be followed, the following trace metals exceeded the value; $\mathrm{Cr}$ of Period 2 which is above $2 \mu \mathrm{g} / \mathrm{L}$; $\mathrm{Cu}$ which is above the minimum value of $0.005 \mu \mathrm{g} / \mathrm{L}$; and $\mathrm{Ni}$ which is above $0.02 \mu \mathrm{g} / \mathrm{L}$. $\mathrm{Cd}$ and $\mathrm{Pb}$ is less than the normal occurrence in drinking water $(<1 \mu \mathrm{g} / \mathrm{L}$ and $<5 \mu \mathrm{g} / \mathrm{L}$, respectively). The $\mathrm{Zn}$ occurrence in the freshwater exceeded the WHO consideration as it is more than the range of $0.01-0.5 \mu \mathrm{g} / \mathrm{L}$. Co is less than the norm. The Canadian Environmental Protection Act, 1999 of the Federal Environmental Quality Guidelines stated that worldwide, Co concentrations is less than $1 \mu \mathrm{g} / \mathrm{L}$ in surface freshwater and $0.3-1.7 \mu \mathrm{g} / \mathrm{L}$ in rainwater. This insinuates that the trace metal concentrations measured in the Pasig River are not negligible. 


\section{Comparison of results to other DGT studies}

2

3

The measured concentrations in this study are compared to other studies that employed DGT in estuaries and coastal waters influenced by anthropogenic activities. For instance, there is an interesting study in the Basque-French estuaries (Montero et al. 2012) situated in an industrial and mining area. The measured concentrations in the Pasig River during Periods 1 and 2 are within the range of the values obtained in this study: Cd (2-1570 ng/L) and Ni (30$3650 \mathrm{ng} / \mathrm{L})$. For $\mathrm{Cu}(66-515 \mathrm{ng} / \mathrm{L})$, the Pasig River has wider range and higher value. The coastal sites of Sardinia in Italy (Schintu et al. 2010) located in a mining and lead-zinc smelting area showed higher $\mathrm{Cu}$ concentration range $(1.45-2.23 \mu \mathrm{g} / \mathrm{L})$. The minimum value of Cd concentration in this site is the maximum value obtained in the Pasig River $(0.9 \mu \mathrm{g} / \mathrm{L})$. Patos Lagoon in Brazil (Costa and Wallner-Kersanach 2013), serves as marina, port and shipyard, has lower $\mathrm{Cu}$ concentration (0.11-0.45 $\mu \mathrm{g} / \mathrm{L})$ than the Pasig River. $\mathrm{Zn}$ maximum concentration of the Pasig River is the minimum value in this site $(0.8 \mu \mathrm{g} / \mathrm{L})$. Baijao site of the Jiulong River in China is characterized as a highly multi-metal contaminated estuary (Weng and Wang 2014). Pasig River has higher $\mathrm{Cd}, \mathrm{Cr}$, and $\mathrm{Pb}$ concentration and wider range compared to this river. Jiulong River has ranges of $0.04-0.12 \mu \mathrm{g} / \mathrm{L}, 1.59-7.72 \mu \mathrm{g} / \mathrm{L}, 0.05-0.39$ $\mu \mathrm{g} / \mathrm{L}$, respectively. The Co concentration of the Pasig River is within the range of the Jiulong River $(0.15-0.95 \mu \mathrm{g} / \mathrm{L})$. The study in the Tama River of Japan considered contrasted weather condition (Aung et al. 2007). In this study, Cu was not detected. Compared to the Pasig River, Tama River Ni, Pb, and Zn concentrations (72 hours deployment: $0.8 \mu \mathrm{g} / \mathrm{L}, 0.39 \mu \mathrm{g} / \mathrm{L}, 3.6$ $\mu \mathrm{g} / \mathrm{L}$, respectively) have higher value than the Pasig River.

As a whole, measured concentrations in the Pasig River correspond to the results of the studies that have shown evident contamination. Although these past studies are relevant, comparing is not easy. True enough that these sites are similar aquatic systems and DGTs were utilized however the conditions were not the same. Case in point is the duration of DGT deployment. DGT samplers in this study were immersed for more than two weeks, whereas, most of the studies are done in shorter periods: Basque-French estuaries: 10 days; Patos Lagoon, Brazil: 72 hours; Sardinia, Italy: 3 days; Tama River, Japan: 46, 48, and 72 hours; and Jiulong River estuary, China: 48 to 72 hours. Besides, not all considered highly seasonal contrasted conditions. Another important issue is that dredging activity was not a component of the reported studies. 
3 Labile trace metals are composed of inorganic and weak complexes species (Gourlay-Francé

\section{Implication on water resources management}

et al. 2011). These species can dissociate and/or has tendency for chemical changes. Serious ecological concerns are arising as these can be dangerous for the microorganisms like phytoplanktons (Baeyens et al. 2011) at a high concentration (Sigg 2014). Hence, it is recommended to measure the labile trace metals to better assess the water quality of the surface water.

The highest trace metal concentration varies according to season (Table 8). Spatial analysis indicates sources of the labile trace metals. For instance, $\mathrm{Cd}$ and $\mathrm{Cr}$ were highest near the bay area (Site 2 during Period 1 and Site 1 for Periods 2 and 3) and Ni was highest close to the lake (Site 4 for Periods 1 and 2 and Site 2 for Period 3). In terms of the lowest concentrations, $\mathrm{Cd}$ has lowest value always near the mouth of the lake. In this area also during Period 3, least concentrations ( $\mathrm{Cd}, \mathrm{Co}, \mathrm{Cr}, \mathrm{Ni}, \mathrm{Pb}$ and $\mathrm{Zn}$ ) were observed.

The Pasig River is in continuous water quality surveillance. The results provide information that trace metal contributes mostly to the natural water system (e.g. $\mathrm{Cr}$ and $\mathrm{Zn}$ ) and needs more monitoring. From this study, water quality measurements can be done according to the susceptibility of the labile trace metals to the spatio-temporal trend. This can give an idea in determining the frequency of sampling campaigns. Labile trace metals that demonstrated spatio-temporal variation (i.e. $\mathrm{Co}, \mathrm{Cu}, \mathrm{Ni}$, and $\mathrm{Pb}$ ) need more sampling frequency. These are more exposed to changes in terms of concentration. Those who are sensitive to seasonal/temporal changes (i.e. $\mathrm{Cd}$ and $\mathrm{Cr}$ ) can entail for lesser sampling campaigns. This is as the former are more vulnerable to labile trace metal contributors or sources. While, the one that exhibited constant change $(\mathrm{Zn})$ does not require high sampling frequency. This means that the order of sampling frequency is as follows: spatio-temporally inclined>seasonally/temporally sensitive>unvarying or constant. These recommendations hold unless unanticipated instantaneous contamination is present (e.g. oil leaks). 


\section{Conclusion}

The study determined the labile trace metals trend in tropical water (estuarine) under episodic event and differing climatic conditions (Period 1: dry and simultaneous dredging; Period 2: intermediate or in between dry and wet; Period 3: wet). If the monsoon regime will be followed: Period 1 was under the transition of winter to summer monsoon; Period 2 was in an event of winter monsoon; and Period 3 encountered summer monsoon.

The periods imply also different physico and hydro-chemical characteristics. This discriminates the trend of trace metals. Considerable amount of trace metals were detected that can be a point of environmental concern especially during Period 2. The general trend found in trace metal concentrations is as follows: Period 2 present the higher one followed by the Period 1 and Period 3 having the lowest concentrations. The trend presented correlations in between the trace metals and physico-chemical parameters. The statistical tests showed that only Period 2 is significantly different from Periods 1 and 3.

The sensitivity of DGT as an in-situ water sampler is established. This is as DGTs were able to follow the trend of the trace metals under contrasted climate conditions and episodic event. Evaluation based from the water quality threshold and other DGT studies proves that substantial trace metals contamination is present in the Pasig River. Furthermore, from the results: 1 . highest trace metals that contribute to the Pasig River were determined $(\mathrm{Cr}$ and $\mathrm{Zn}$ ); 2. three (3) trends of trace metals were identified: (i) spatio-temporally inclined; (ii) seasonally or temporally sensitive; (iii) constant or unvarying; and 3. the can latter facilitate in deciding the frequency of sampling or monitoring. The precedence is of this order: spatiotemporally inclined (i.e. $\mathrm{Co}, \mathrm{Cu}, \mathrm{Ni}$ and $\mathrm{Pb}$ )>seasonally/temporally sensitive (i.e. $\mathrm{Cd}$ and $\mathrm{Cr}$ )> unvarying or constant (i.e. $\mathrm{Zn}$ ).

This study provides sound baseline information on the state of the water quality and its response to seasonal changes and environmental disturbance. It proves that the Pasig River is susceptible to these changes and disturbance as depicted by the variation of the values obtained from physico-chemical parameters and labile trace metal concentrations. Furthermore, major results presented that on one hand, intermediate season (from dry to wet) can bring higher concentration of trace metals than the environmental disturbance (dredging). On the other hand, continues rainfall can cause washing effect through dilution (as the concentration of the labile trace metals notably diminished except for $\mathrm{Zn}$ ). 


\section{Acknowledgement}

12

23

This research was funded by the Lyonnaise des Eaux Company, Bordeaux, France and was done with 4 the help of the Pasig River Rehabilitation Commission (PRRC), LCDR Christopher Meniado of the Philippine 5 Coast Guards (PCG) and his staff, the Department of Natural Resources and Environment-Environmental 6 Management Bureau (DENR-EMB) and Dr. Gemma Narisma, Genie Lorenzo and James Simpas of the Manila 7 Observatory. The authors are also grateful to the French Embassy in the Philippines for giving financial 8 assistance for field mobility, the European Union ERASMUS MUNDUS External Cooperation Window (ECW) 9 Lot 12/13 and the Bourse Eiffel Excellence (Programme 2012-2013) from the French Ministry of Foreign 10 Affairs for providing the academic grant and to Prof. Jorg Schäfer, Dr. Farah Homsi and Mr. Patrick Sin for all 11 their technical inputs and support; and M. Jean Bernard Delmas for his encouragements. 


\section{References}

Aiga H, Umenai T (2002) Impact of improvement of water supply on household economy in a squatter area of Manila. Soc. Sci. Med. 55:627-641. DOI:10.1007/BF02932265. PMCID: PMC2723519.

Alfaro-De la Torre MC, Beaulieu PY, Tessier A (2000) In situ measurement of trace metals in lakewater using the dialysis and DGT techniques. Anal. Chim. Act. 418:53-68. DOI:10.1016/S0003-2670(00)00946-6.

Atkinson CA, Jolley DF, Simpson SL (2007) Effect of overlying water pH, dissolved oxygen, salinity and sediment disturbances on metal release and sequestration from metal contaminated marine sediments. Chemosphere. 69:1428-1437. DOI: 10.1021/es4009272.

Audry S, Jörg S, Blanc G, Bossy C, Lavaux G (2004) Anthropogenic components of heavy metal $(\mathrm{Cd}, \mathrm{Zn}, \mathrm{Cu}, \mathrm{Pb})$ budgets in the Lot-Garonne fluvial system (France). Appl Geochem 19:769-786. DOI: 10.1016/j.apgeochem.2003.10.002

Aung NN, Nakajima F, Furumai H (2008) Trace metal speciation during dry and wet weather flows in the Tama River, Japan, by using diffusive gradients in thin films (DGT). J. Environ. Manage. 10:219-230. DOI: 10.1016/0165-9936(81)80014-3.

Baeyen W, Bowie AR, Buesseler K, Elskens M, Gao Y, Lamborg C, Leermakers M, Remenyi T, Zhang H (2011) Size-fractionated labile trace elements in the Northwest Pacific and Southern Oceans. Marine Chemistry 126:108-113. DOI:10.1016/j.marchem.2011.04.004

Biati A, Karbassi AR, Hassani AH, Monavari SM, Moattar F (2010) Role of metal species in flocculation rate during estuarine mixing. International Journal of Science and Technology 2:327-336. ISSN: 1735-1742. DOI: 10.1007/BF03326142.

Boughriet A, Oudane B, Fisher JC, Wartel FM, Leman G (1992) Variability of Dissolved Mn and $\mathrm{Zn}$ in the Seine Estuary and chemical speciation of these metals in suspended matter. Wat. Res. 26:10,1359-1378. DOI: 10.1016/0043-1354(92)90130-V

Breckel EJ, Emerson S, Balistrieri LS (2005) Authigenesis of trace metals in energetic tropical shelf environments. Cont. Shelf. Res. 25:1321-1337. DOI: 10.1016/j.csr.2005.02.001.

Buckly BM, Fletcher R, Wang S-Y S, Zottoli B, Pottier C (2014) Monsoon extremes and society over the past millennium on mainland Southeast Asia. Quat. Sci. Rev. 95:1-19. http://dx.doi.org/10.1016/j.quascirev.2014.04.022.

Buffle J, van Leeuwen HP (1992) Environmental Particles. Environmental and physical chemistry series.Volume 1, Lewis Publishers, Inc.

Buffle J, van Leeuwen HP (1993) Environmental Particles. Environmental Analytical and Physical Chemistry Ser. CRC Press ISBN-13.9780873718950

Cabrita MT (2014) Phytoplankton community indicators of changes associated with dredging in the Tagus estuary (Portugal). Environ. Pollut. 191:17-24. DOI:10.1016/j.envpol.2014.04.001.

Chakraborty P, Babu PVR, Acharyya T, Bandyopadhyay D (2010) Stress and toxicity of biologically important transition metals ( $\mathrm{Co}, \mathrm{Ni}, \mathrm{Cu}$ and $\mathrm{Zn}$ ) on phytoplankton in a tropical freshwater system: An investigation with pigments analysis by HPLC. Chemosphere 80:548-553. DOI: 10.1016/j.chemosphere.2010.04.039. 
Chen J, Zhang R, Wang H, Li J, Hong M, Li X (2014) Decadal modes of seas surface salinity and the water cycle in the tropical Pacific Ocean: The anomalous late 1990.Deep-Sea Res. PT I 84:38-49. DOI:10.1016/j.dsr.2013.10.005.

Clarisse O, Foucher D, Hintelmann H (2009) Methylmercury speciation in the dissolved phase of a stratified lake using the diffusive gradient in thin film technique. Environ. Pollut.157:987-993. DOI:10.1016/j.envpol.2008.10.012.

Cook CG, Jones RT (2012) Paleoclimatic dynamics in continental Southeast Asia over the last $\sim 30,000$ Cal yrs BP. Palaeogeogr. Palaeoclimatol. Palaeoecol. 339-341:1-11. DOI:10.1016/j.palaeo.2012.03.025.

Costa LD, Wallner-Kersanach M (2013) Assessment of the labile fractions of copper and zinc in marinas and port areas in Southern Brazil. Environ. Assess. 185:6767-6781. DOI: $10.1007 / \mathrm{s} 10661-013-3063-0$.

Cruz FT, Narisma TG, Villafuerte II MQ Cheng-Chua KU, Olaguera LM (2012) A climatological analysis of the southwest monsoon rainfall in the Philippines. Atmos. Res. 122:609-616. DOI: 10.1016/j.atmosres.2012.06.010

Davison W, Zhang H (1999) Diffusional characteristics of hydrogel used in DGT and DET techniques. Anal.Chim.Acta 398:329-340. DOI:10.1007/s10661-013-3063-0

DGT Research (2002) DGT-for measurements in water, soils and sediments. DGT Research Ltd., Lancaster.

Dudka S, Piotrowska M, Chlopecka A (1994) Effect of elevated concentrations of Cd and Zn in soil on spring wheat yield and the metal contents of the plants. Water Air Soil. Pollut.76:333-341. DOI:10.1007/BF00482710.

Dunn RJK, Teasdale PR, Warnken J, Jordan MA, Arthur JM (2007) Evaluation of the in situ, time-integrated DGT technique by monitoring changes in heavy metal concentrations in estuarine waters. Environ. Pollut. 148:213-220. DOI:10.1016/j.envpol.2006.10.027.

Fathollahzade H,Kaczala F, Bhatnagar A, Hogland W (2015) Significance of environmental dredging on metal mobility from contaminated sediments in the Oskarshamn Harbor, Sweden. Chemosphere 119:445-451. DOI:10.1016/j.chemosphere.2014.07.008.

Fritz M, Berger PD (2015) Comparing two designs (or anything else!) using paired sample TTests. Improving the User Experience Through Practical Data Analytics. Chapter 3 :71-89. DOI: 10.1016/B978-0-12-800635-1.00003-3

Fuchs R, Dupouy C, Douillet P, Caillaud M, Mangin A, Pinazo C (2012). Modelling the impact of a La Niña event on a South West Pacific Lagoon. Marine Poll. Bull. 64:1596-1613. http://dx.doi.org/10.1016/j.marpolbul.2012.05.016.

Gao Y, Baeyens W, De Galan S, Poffijn A, Leermakers M (2010) Mobility of radium and trace metals in sediments of the Winterbeek: Application of sequential extraction and the DGT techniques. Environ. Pollut.158:2439-2445. DOI:10.1016/j.envpol.2010.03.022.

Gerringa LJA, de Baar HJW, Nolting RF, Paucot H (2001) The influence of the salinity on the solubility of $\mathrm{Zn}$ and $\mathrm{Cd}$ sulphides in the Scheldt estuary. J. of Sea Res. 46:201-211. DOI:10.1016/S1385-1101(01)00081-8.

Gourlay-Francé C, Bressy A, Uher E, Lorgeoux C (2011) Labile, dissolved and particulate PAHs and trace metals in wastewater passive sampling, occurrence, partitioning in treatment plants. Water. Sci. Technol. 63:7:1327-33. DOI:10.2166/wst.2011.127. DOI: 10.2166/wst.2011.127. 
Gottesmann W, Kampe A (2007) $\mathrm{Zn} / \mathrm{Cd}$ ratios in calcsilicate-hosted sphalerite ores at Tumurtijn-ovoo, Mongolia. DOI:10.1016/j.chemer.2007.01.002

Chemie der Erde

67:323-328.

Graveline N, Maton L, Luckge H, Rouillard J, Strosser P, Palkaniete K, Rinaudo J-D, Taverne D, Interwies E (2010) An operational perspective on potential uses and constraints of emerging tools for monitoring water quality. TrAC 29:5. DOI: 10.1016/j.trac.2010.02.006

Gurumurthy GP, Balakrishna K, Tripti M, Audry S, Riotte J, Braun JJ, Udaya Shankar HN river basin, Southwestern India. Environ. Sci. Pollut. Res. DOI.10.1007/s11356-013-2462-7

Han W, Moore AM, Levin J, Zhang B, Arango HG, Curchitser E, Di Lorenzo E, Gordon AL, Lin J (2009) Seasonal surface ocean circulation and dynamics in the Philippine Archipelago region during 2004-2008. Dynam. Atmos. Oceans 47:114-137. DOI:10.1016/j.dynatmoce.2008.10.007

Hatje V, Apte SC, Hales LT, Birch GF (2003) Dissolved trace metal distribution in Port Jackson estuary (Sydney Harbour), Australia. Mar. Pollut. Bull. 46:719-730. DOI:10.1016/S0025-326X(03)00061-4

Herngren L, Goonetilleke A, Ayoko GA (2005) Understanding heavy metal and suspended solids relationships in urban stormwater using simulated rainfall. J. Envrion. Manage. 76:149-158. DOI:10.1016/j.jenvman.2005.01.013.

Hestir EL, Schoellhamer DH, Morgan-King T, Ustin SL (2013) A step decrease in sediment concentration in a highly modified tidal river delta following the 1983 El Niño floods. Mar. Geol. 345:304-313. http://dx.doi.org/10.1016/j.margeo.2013.05.008

INAP (2002) Diffusive Gradients in Thin-Films.A technique for Determining Bioavailable Metal Concentrations. Theory and Application Literature Surveyhttp://www.inap.com.au/public_downloads/Research_Projects/Diffusive_Gradients_i n_Thin-films.pdf

Je C, Hayes DF, Kim KS (2007) Simulation of resuspended sediments resulting from dredging operations by a numerical flocculent transport model. Chemosphere 70:187-195. DOI:10.1016/j.chemosphere.2007.06.033

Jiann KT, Wen LS (2009) Intra-annual variability of distribution patterns and fluxes of dissolved trace metals in a subtropical estuary (Danshuei River, Taiwan). J. Mar. Syst. 75:87-99. DOI:10.1016/j.jmarsys.2008.08.002.

Kuehl SA, Nittrouer CA, Allison MA, Faria LEC, Dukat DA, Jaeger JM, Pacioni TD, Figueiredo AG, Underkoffler EC (1996) Sediment deposition, accumulation, and seabed dynamics in an energetic fine-grainedcoastal environment. Cont. Shelf Res. 5/6:787815. DOI:10.1016/0278-4343(95)00047-X.

Lewis MA, Weber DE, Stanley RS, Moore JC (2001) Dredging impact on an urbanized Florida bayou: effects on benthos and algal-periphyton. Environ. Pollut. 115:161-171. DOI:10.1016/S0269-7491(01)00118-X.

Li W, Zhao H, Teasdale PR, Wang F (2005) Trace metal speciation measurements in waters by the liquid binding phase DGT device. Talanta 67:3:571-578. DOI:10.1016/j.talanta.2005.03.018. 
Loo YY, Billa L, Singh A (2014) Effect of climate change on seasonal monsson in Asia and its impact on the variability of monsoon rainfall in Southeast Asia. GSF xxx:1-7. DOI:10.1016/j.gsf.2014.02.009

4 Mackie JA, Natali SM, Levinton JS, Sanudo-Wilhelmy SA (2007) Declining metal levels at Foundry Cove (Hudson River, New York): Response to localized dredging of contaminated sediments. Environ. Pollut. 149:141-148. DOI:10.1016/j.envpol.2007.01.010.

Masson M, Blanc G, Schäfer J (2006) Geochemical signals and source contributions to heavy metal $(\mathrm{Cd}, \mathrm{Zn}, \mathrm{Pb}, \mathrm{Cu})$ fluxes into the Gironde Estuary via its major tributaries. Sci. Total. Environ. 370:133-146. DOI: 10.1016/j.scitotenv.2006.06.011.

Masson M, Blanc G, Schäfer J, Parlanti E, Le Coustumer P (2011) Copper addition by organic matter degradation in the freshwater reaches of a turbid estuary. Sci. Total Environ. 409:8:1539-1549. DOI:10.1016/j.scitotenv.2011.01.022.

Materum R (2010) Physicochemical and particulate characterization of selected urbanimpacted aquatic systems in Manila (The Philippines) and Bordeaux (France). Rapport de Stage. FDEA. Université Bordeaux 1

Mazeina LP, Bessonov DU, Bortnikova SB (1999) Zinc and Cadmium behaviour in tailings. Geochemistry of the Earth's Surface, Armannsson (ed.) Balkerna, Rotterdam, ISBN 905809 0736

Meybeck M (2009) Asia-Monsoon Asia. Rivers and Streams.- Gems Water program UNEP, global river water quality data. http://www.gemsstat.org/descstats.aspx

Migliavacca D, Teixeira EC, Wiegand F, Machado ACM, Sanchez J (2005) Atmospheric precipitation and chemical composition of an urban site, Guaíba hydrographic basin, Brazil. Atmos. Environ. 39:1829-1844. DOI:10.1016/j.atmosenv.2004.12.005.

Montero N, Belzunce-Segarra MJ, Gonzalez JL, Larreta J, Franco J (2012) Evaluation of diffusive gradient in thin films (DGT) as a monitoring tool for the assessment of the chemical status of transitional waters within the Water Framework Directive. Mar. Poll. Bull. 64:31-39. DOI: 10.1016/j.marpolbul.2011.10.028.

Munk LA, Faure G, Pride DE, Bigham JM (2002) Sorption of trace metals to an aluminum precipitate in a stream receiving acid rock-drainage; Snake River, Summit County, Colorado. Appl. Geochem. 17:421-430. DOI:10.1016/S0883-2927(01)00098-1.

Nayar S, Goh BPL, Chou LM (2004) Environmental impact of heavy metals from dredged and resuspended sediments on phytoplankton and bacteria assessed in in situ mesocosms. Ecotox. Environ. Safe 59:349-369. DOI:10.1016/j.ecoenv.2003.08.015

Naylor C, Davison W, Motelica-Heino M, Van den Berg GA, Van Der Heidjt LM (2004) Simultaneous release of sulfide with $\mathrm{Fe}, \mathrm{Mn}, \mathrm{Ni}$ and $\mathrm{Zn}$ in marine harbor sediment measured using a combined metal/sulfide DGT probe. Sci. Total Environ. 328:275286. DOI: 10.1016/j.scitotenv.2004.02.008.

Neal C, Smith CJ, Jeffrey HA, Harrow M, Neal M (1996) Dissolved chromium pollution in rainfall and surface waters in mid-Wales during the mid-1980s. Sci. Total Environ. 188:2-3, 127-138. DOI:10.1016/0048-9697(96)05180-7.

Nolting RF, de Baar HJW, Timmermans KR, Bakker K (1999) Chemical fractionation of zince versus cadmium among other metals nickel, copper and lead in the northern North Sea. Mar Chem 67:267-287. DOI: 10.1016/S0304-4203(99)00076-6 
Özsoy T, Örnektekin S (2009) Trace elements in urban and suburban rainfall, Mersin, Northeastern Mediterranean. Atmos. Res. 94:203-219. DOI:10.1016/j.atmosres.2009.05.017. Park JH, Inam E, Abdullah MH, Agustiyani D, Duan L, Thuong Hoang T, Kim KW, Kim SD, Nguyen MN, Pekthong T, Sao V, Sariya A, Savathvong S, Sthiannopkao S, Syers JK, Wirojanad W (2011) Implications of rainfall variability for seasonal and climate-induced risks concerning surface water quality in East Asia. J. Hydrol. 400:323-332. DOI: 10.1016/j.jhydrol.2011.01.050.

Pettke T, Oberli F, Audétat A, Guillong M, Simon A, Hanley J, Klemm L (2012) Recent developments in element concentration and isotope ratio analysis of individual fluid inclusion by laser ablation, single and multiple collector ICP-MS. Ore Geol. Rev. 44:10-38. DOI: 10.1016/j.oregeorev.2011.11.001.

Pinheiro JP, Domingos RF (2005) Impact of spherical diffusion on labile trace metals speciation by electrochemical stripping techniques. J. Electroanal. Chem. 581:167-175. DOI:10.1016/j.jelechem.2004.12.024

Schintu M, Marras B, Durante L, Meloni P, Contu A (2010) Macroalgae and DGT as indicators of available trace metals in marine coastal waters near a lead-zinc smelter. Environ. Monit. Assess. 167:653-661. DOI 10.1007/s10661-009-1081-8

Shirasago-Germán B, Pérez-Lezama EL, Chávez EA (2015) Influence of El Niño-Southern Oscillation on the population structure of a sea lion breeding colony in the Gulf of California. Estuar. Coast. Shelf. S. 154:69-76. http://dx.doi.org/10.1016/j.ecss.2014.12.024

Sigg L (2014) 4.15-Metals as water quality parameters-Role of speciation and Bioavailability. Reference Module in Earth Systems and Environmental Sciences. Comprehensive Water Quality and Purification. 4:315-328. DOI:10.1016/B978-0-12-382182-9.00090-6

Sokolowski A, Wolowicz M, Hummel H (2001) Distribution of dissolved and labile particulate trace metals in the Overlying bottom water in the Vistula River Plume (Southern Baltic Sea). Mar. Pollut. Bulletin 42:10:967-980. PII: S0025-326X(01)00069-8. DOI:10.1016/S0025326X(01)00069-8

Søndergaard J, Elberling B, Asmund G (2008) Metal speciation and bioavailability in acid mine drainage from a high Arctic coal mine waste rock pile: Temporal variations assessed through high-resolution water sampling, geochemical modeling and DGT. Cold Reg. Sci. Technol 54:89-96. DOI:10.1016/j.coldregions.2008.01.003.

Stephens M, Mattey D, Gilbertson DD, Murray-Wallace CV (2008) Shell-gathering from mangroves and seasonality of the Southeast Asian Monsoon (Geloina erosa) from the Great Cave of Niah, Sarawak: methods and reconnaissance of mollusks of early Holocene and modern times. J. Archaeol. Sci. 35:2686-2697. DOI:10.1016/j.jas.2008.04.025

Sokolowski A, Wolowicz M, Hummel H (2001) Distribution of dissolved and labile particulate trace metals in the Overlying bottom water in the Vistula River Plume (Southern Baltic Sea), Mar.Pollut. Bull. 42(10): 967-980. http://dx.doi.org/10.1016/S0025-326X(01)00069-8

Takahashi, HG (2013) Orographic low-level clouds of Southeast Asia during the cold surges of the winter monsoon. Atmos. Res. 131:22-33. DOI:10.1016/j.atmosres.2012.07.005

van den Berg GA, Meijers GG, van der Heijdt LM, Zwolsman JJ (2001) Dredging-related mobilisation of trace metals: a case study in The Netherlands. Water Res. 35:8:1979-86. DOI:10.1016/S0043-1354(00)00452-8 
vanLoon W, Duffy SJ (2000) Environmental Chemistry: A Global Perspectives. Oxford University Press Incorporated. ISBN 0198564406, 9780198564409

3 Varis O, Kummu M, Salmivaara A (2012) Ten major rivers in monsoon Asia-Pacific: An assessment of vulnerability. Appl. Geogr. 32:441-454. DOI:10.1016/j.apgeog.2011.05.003.

Viers J, Dupré B, Gaillardet J (2009) Chemical composition of suspended sediments in World Rivers: New insights from a new database. Sci. Total. Environ. 407:853-868. DOI:10.1016/j.scitotenv.2008.09.053.

Villafuerte II MQ, Matsumoto J, Akasaka I, Takahashi HG, Kubota H, Cinco TA (2014) Longterm trends and variability of rainfall extremes in the Philippines. Atmos. Res. 137:1-13. DOI: 10.1016/j.atmosres.2013.09.021.

Villanueva JD (2013) Suivi par capteurs passifs des polluants émergents dans les eaux de surface en contexte urbain (Monitoring emerging pollutants in surface waters using in situ sampling devices in an urban context), Ph. D. thesis, Université Bordeaux, France

Villanueva JD, Le Coustumer P, Huneau F, Motelica-Heino M, Perez TR, Materum R, Espaldon MVO, Stoll, S (2013) Assessment of trace metals during episodic events using DGT passive sampler: A proposal for water management enhancement. Water Resour. Manag. 27:12:4163-4181. DOI: 10.1007/s11269-013-0401-5.

Vystavna Y, Huneau F, Motellica-Heino M, Le Coustumer P, Vergeles Y, Stolberg F (2012a) Monitoring and flux determination of trace metals in rivers of the Seversky Donets basin (Ukraine) using DGT passive samplers. Environ .Earth. Sci. 65:1715-1725. DOI: $10.1007 / \mathrm{s} 12665-011-1151-4$

Vystavna Y, Huneau F, Schäfer J, Motellica-Heino M, Blanc G, Larrose A, Veregeles Y, Dyadin D, Le Coustumer P (2012b) Distribution of trace elements in waters and sediments of the Seversky Donets transboundary watershed (Kharkiv region, Eastern Ukraine). Appl. Geochem. 27:2077-2087. DOI: 10.1016/j.apgeochem.2012.05.006.

Weng N, Wang WX (2014) Variations of trace metals in two estuarine environments with contrasting pollution histories. Sci. Total. Environ. 485-486:604-614. DOI:10.1016/j.scitotenv.2014.03.110.

Wilkerson FP, Dugdale RC, Marchi A, Collins CA (2002) Hydrography, nutrients and chlorophyll during El Niño and La Niña 1997-99 winters in the Gulf of the Farallones, California. Progr. Oceanogr. 54:293-310; DOI: 10.1016/S0079-6611(02)00055-1.

Witt MLI, Mather TA, Baker AR, De Hoog JCM, Pyle DM (2010) Atmospheric trace metals over the south-west Indian Ocean: Total gaseous mercury, aerosol trace metal concentrations and lead isotope ratios. Mar. Chem. 121:2-16. DOI: 10.1016/j.marchem.2010.02.005

Vuai SAH, Tokuyama A (2011) Trend of trace metals in precipitation around Okinawa Island, Japan, Atmos. Res. 99:80-84. DOI: 10.1016/j.atmosres.2010.09.010

World Health Organization (2008) Guidelines for drinking-water quality. Vol. 1 3rd Ed., ISBN 9789241547611

Wu Z, He M, Lin C (2011) In situ measurements of concentrations of Cd, Co, Fe and Mn in estuarine porewater using DGT. Environ. Pollut. 159:1123-1128. DOI:0.1016/j.envpol.2011.02.015.

Zhang H, Davison W, Miller S, Tych, W (1995) In situ high resolution measurements of fluxes of $\mathrm{Ni}, \mathrm{Cu}, \mathrm{Fe}$, and $\mathrm{Mn}$ and concentrations of $\mathrm{Zn}$ and $\mathrm{Cd}$ in porewaters by DGT. Geochim. Cosmochim. Ac. 59:20:4181-4192. DOI:10.1016/0016-7037(95)00293-9 
1 Zwolsman JJG, Van Eck GTM (1993) Dissolved and particulate trace metal geochemistry in 2 the Scheldt estuary, S.W. Netherlands (water column and sediments). Neth. J. Aquat. Ecol. 3 2:4:287-300. DOI: 10.1007/BF02334792. 
Table 1 Rainfall rate during the sampling campaigns.

\begin{tabular}{llll}
\hline Rainfall (mm) & Period 1 & Period 2 & Period 3 \\
\hline
\end{tabular}

Days before sampling*

$\begin{array}{lccc}10 & 0.8 & 5.4 & 19.6 \\ 20 & 0.8 & 14.4 & 125.2\end{array}$

Accumulated within the sampling period

$\begin{array}{lll}6 & 79 & 79.8\end{array}$

3 *Days before DGT installation

$4 \quad$ Provided by Manila Observatory (unpublished data 2012)

5

6

Table 2 Physico-chemical parameters' range of values

\begin{tabular}{cccccr}
\hline Period & $\begin{array}{c}\text { Water } \\
\text { temperature }\left({ }^{\circ} \mathbf{C}\right)\end{array}$ & DO $(\mathbf{m g} / \mathbf{L})$ & $\mathbf{p H}$ & Salinity & $\begin{array}{c}\text { Conductivity } \\
(\mathbf{m s} / \mathbf{c m})\end{array}$ \\
\hline & 31 & $0.45-1.05$ & $7.89-8.35$ & $0.55-3.60$ & $6.00-22.00$ \\
1 & $26-27$ & $5.90-8.20$ & $7.31-7.73$ & $0.39-0.40$ & $0.81-0.84$ \\
2 & $31-32$ & $1.55-2.26$ & $6.80-7.03$ & $0.39-8.44$ & $1.00-16.00$ \\
3 & & & & & \\
\hline
\end{tabular}

Table 3 Concentration range of detected labile trace metals inthe Pasig River (ng/L)

\begin{tabular}{crrrrrrr}
\hline Trace metals & \multicolumn{4}{c}{ Concentration ranges } & \multicolumn{2}{c}{ RSD } & Detection \\
& Period 1 & Period 2 & Period 3 & Period 1 & Period 2 & Period 3 & Limit \\
\hline & & & & & & & \\
$\mathrm{Cd}$ & $87-94$ & $141-146$ & $0.9-1.8$ & 1.75 & 1.04 & 0.19 & 0.21 \\
$\mathrm{Co}$ & $28-82$ & $119-277$ & $62-100$ & 11.24 & 34.27 & 9.09 & 6.44 \\
$\mathrm{Cr}$ & $205-236$ & $6841-7632$ & $13-23$ & 6.82 & 184.50 & 2.15 & 10.86 \\
$\mathrm{Cu}$ & $88-314$ & $506-867$ & $149-251$ & 48.93 & 82.92 & 23.17 & 7.63 \\
$\mathrm{Ni}$ & $154-434$ & $206-255$ & $22-27$ & 61.33 & 12.57 & 1.09 & 2.94 \\
$\mathrm{~Pb}$ & $95-122$ & $50-643$ & $7-16$ & 6.95 & 131.25 & 2.18 & 1.21 \\
$\mathrm{Zn}$ & $827-1027$ & $793-1236$ & $431-1468$ & 42.34 & 103.60 & 232.11 & 100.00 \\
\hline
\end{tabular}


1 Table 4 Anthropogenic activities surrounding the Pasig River and the major trace metals

2 concern

\begin{tabular}{lll}
\hline Site & Important activities & \multicolumn{1}{c}{ Major metals co } \\
& shipyard & $\mathrm{Ni}$ \\
& ceramic factory & $\mathrm{Co}, \mathrm{Cr}, \mathrm{Pb}$ \\
& electric company & $\mathrm{Cu}$ \\
Site $\mathbf{1}$ & textile and clothing & $\mathrm{Cr}, \mathrm{Zn}$ \\
& thermal power plant & $\mathrm{Cd}, \mathrm{Ni}, \mathrm{Pb}, \mathrm{Zn}$ \\
& food company & $\mathrm{Pb}, \mathrm{Cu}$ \\
& gasoline stations & $\mathrm{Cd}, \mathrm{Co}, \mathrm{Cr}, \mathrm{Cu}, \mathrm{Ni}, \mathrm{Pb}, \mathrm{Zn}$ \\
& oil refinery & $\mathrm{Cd}, \mathrm{Cr}, \mathrm{Pb}$ \\
& navigational lane & $\mathrm{Cd}, \mathrm{Co}, \mathrm{Cr}, \mathrm{Cu}, \mathrm{Ni}, \mathrm{Pb}, \mathrm{Zn}$ \\
& oil refinery & $\mathrm{Cd}, \mathrm{Cr}, \mathrm{Pb}$ \\
& steel & $\mathrm{Cr}$ \\
& oil and petroleum company & $\mathrm{Cd}, \mathrm{Co}, \mathrm{Pb}, \mathrm{Zn}$ \\
& & \\
& & $\mathrm{Cu}$ \\
& wood 2 & $\mathrm{Cu}$ \\
& electricity (electrical industry) & $\mathrm{Cd}$ \\
& cigarettes & $\mathrm{Co}, \mathrm{Cr}, \mathrm{Ni}, \mathrm{Zn}$ \\
& metal castings & $\mathrm{Cd}, \mathrm{Cu}, \mathrm{Pb}$ \\
& agroindustry & $\mathrm{Cr}, \mathrm{Ni}$ \\
& steels & \\
& & $\mathrm{Cd}, \mathrm{Co}, \mathrm{Cr}, \mathrm{Cu}, \mathrm{Ni}, \mathrm{Pb}, \mathrm{Zn}$
\end{tabular}

Site 4 fishing, irrigation

$\mathrm{Cd}, \mathrm{Zn}$

power generation

$\mathrm{Cd}, \mathrm{Pb}$

navigational lane

$\mathrm{Cd}, \mathrm{Co}, \mathrm{Cr}, \mathrm{Cu}, \mathrm{Ni}, \mathrm{Pb}, \mathrm{Zn}$

3 
1 Table 5 Student t-test result. *For 5\% level of significance, there is difference on the mean response of Dry vs. Intermediate, and Intermediate vs. Wet as showed in the p-values. (sig. < $0.05)$

\begin{tabular}{|c|c|c|c|c|c|c|}
\hline & Groups & $\mathbf{t}$ & df & $\begin{array}{c}\text { sig. } \\
(2 \\
\text { tailed }) \\
\end{array}$ & $\begin{array}{c}\text { MeanDifferenc } \\
\mathrm{e}\end{array}$ & $\begin{array}{c}\text { Std. } \\
\begin{array}{c}\text { ErrorDifferenc } \\
\mathrm{e}\end{array} \\
\end{array}$ \\
\hline \multirow{3}{*}{ בְ } & $\begin{array}{l}\text { Dry(1) } \\
\text { vs.Intermediate(2) } \\
\text { ○o }\end{array}$ & -2.43 & 27.77 & $0.022 *$ & -1109.41 & 455.75 \\
\hline & Dry(1) vs.Wet(3) & 0.78 & 54.00 & 0.437 & 69.74 & 89.09 \\
\hline & $\begin{array}{l}\text { Intermediate(2) } \\
\text { vs.Wet(3) } \\
\text { oo }\end{array}$ & 2.57 & 28.32 & $0.016^{*}$ & 1179.15 & 458.05 \\
\hline
\end{tabular}

8 Table 6 Correlation $(r)$ among physico-chemical parameters

\begin{tabular}{lcccc}
\hline Salinity & $\begin{array}{c}\text { Dissolved } \\
\text { oxygen }\end{array}$ & $\begin{array}{c}\text { Water } \\
\text { Temp }\end{array}$ & pH & Conductivity \\
\hline
\end{tabular}

\begin{tabular}{lrrrrr} 
Salinity & 1.00 & & & & \\
Dissolved oxygen & -0.42 & 1.00 & & & \\
Water Temp & 0.36 & -0.92 & 1.00 & & \\
pH & -0.40 & -0.25 & 0.09 & 1.00 & \\
Conductivity & 0.69 & -0.70 & 0.52 & 0.26 & 1.00 \\
\hline
\end{tabular}

9 
1 Table 7 Correlation $(r)$ : among labile trace metals and labile trace metals to the physico-

$\begin{array}{lll}1 & 2 \text { chemical parameters }\end{array}$

\begin{tabular}{lrrrrrrr}
\hline & Cd & Co & Cr & Cu & Ni & Pb & Zn \\
\cline { 2 - 8 } Cd & 1.00 & & & & & & \\
Co & 0.48 & 1.00 & & & & & \\
Cr & 0.80 & 0.77 & 1.00 & & & & \\
Cu & 0.71 & 0.69 & 0.92 & 1.00 & & & \\
Ni & 0.75 & 0.12 & 0.38 & 0.28 & 1.00 & & \\
Pb & 0.68 & 0.71 & 0.69 & 0.47 & 0.40 & 1.00 & \\
Zn & -0.04 & 0.06 & 0.06 & 0.16 & -0.12 & -0.14 & 1.00 \\
pH & 0.52 & -0.25 & -0.06 & -0.04 & 0.75 & 0.08 & -0.13 \\
Salinity & -0.59 & -0.28 & -0.48 & -0.48 & -0.52 & -0.41 & 0.53 \\
DO & 0.65 & 0.88 & 0.95 & 0.84 & 0.24 & 0.76 & -0.02 \\
Water Temp & -0.78 & -0.77 & -0.98 & -0.91 & -0.28 & -0.67 & -0.18 \\
Conductivity & -0.29 & -0.60 & -0.63 & -0.63 & -0.12 & -0.38 & 0.25 \\
\hline
\end{tabular}

3

4 Table 8 Detected sites which have highest and lowest labile trace metal concentrations

\begin{tabular}{ccccccc}
\hline Trace & \multicolumn{2}{c}{ Site of highest concentration } & \multicolumn{3}{c}{ Site of lowest concentration } \\
metals & Period 1 & Period 2 & Period 3 & Period 1 & Period 2 & Period 3 \\
\hline $\mathrm{Cd}$ & 2 & 1 & 1 & 4 & 4 & 4 \\
$\mathrm{Co}$ & 3 & 4 & 2 & 1 & 3 & 4 \\
$\mathrm{Cr}$ & 2 & 1 & 1 & 4 & 2 & 4 \\
$\mathrm{Cu}$ & 3 & 1 & 3 & 4 & 2 & 1 \\
$\mathrm{Ni}$ & 4 & 4 & 3 & 2 & 3 & 4 \\
$\mathrm{~Pb}$ & 2 & 4 & 2 & 4 & 1 & 4 \\
$\mathrm{Zn}$ & 3 & 3 & 2 & 4 & 2 & 4 \\
\hline
\end{tabular}

5

Site 1: near Manila Bay; Sites 2 and 3: midstream; Site 4: near Laguna Lake 


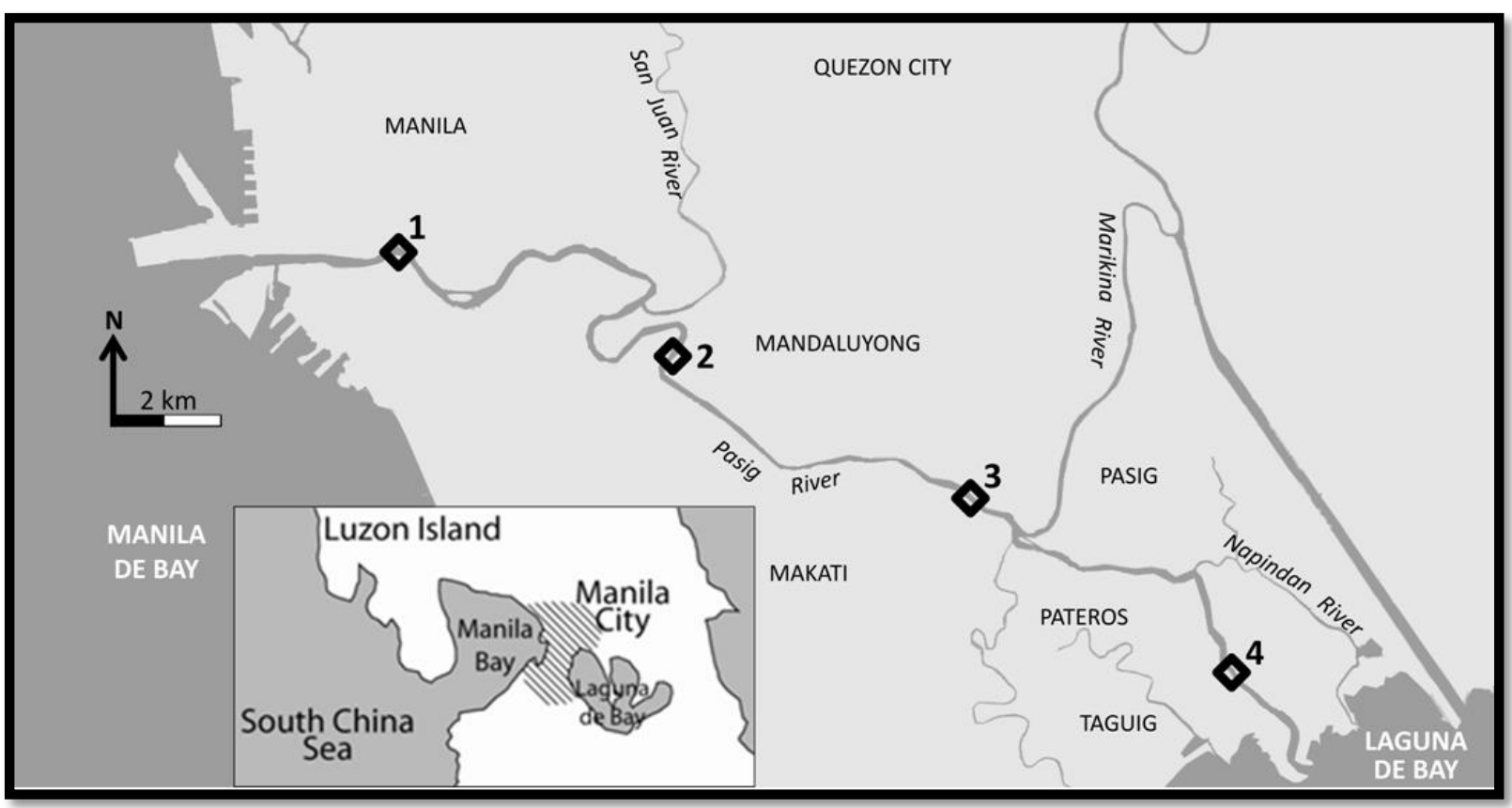

Fig. 1 The Pasig River map and sampling sites (Point 1: moth of the Manila Bay; Point 2: near the convergence of the San Juan River, Point 3: near the confluence of the Marikina River; and Point 4: near the Laguna Lake) 


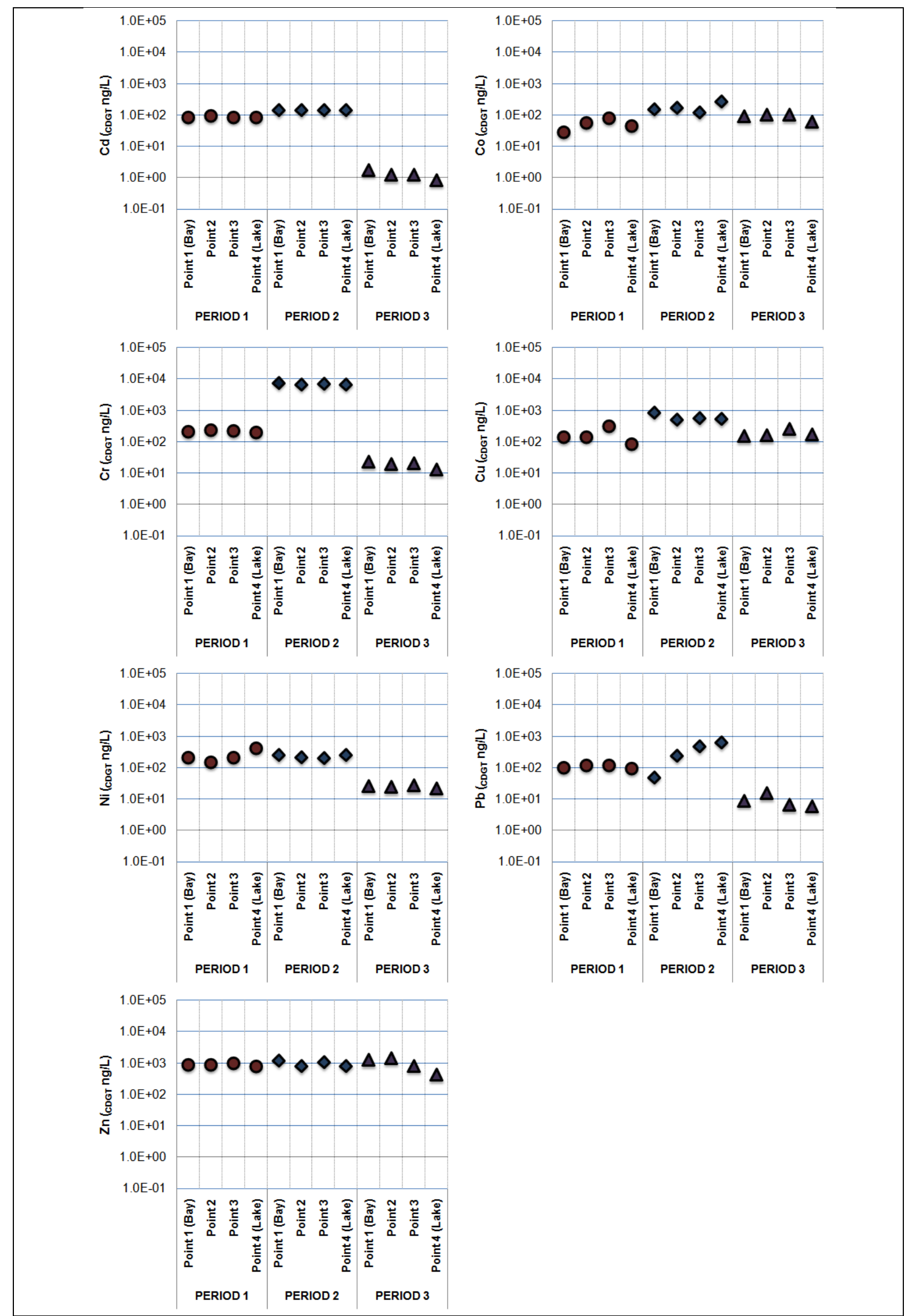

Fig. 2 DGT-labile trace metals' concentrations (ng/L) 


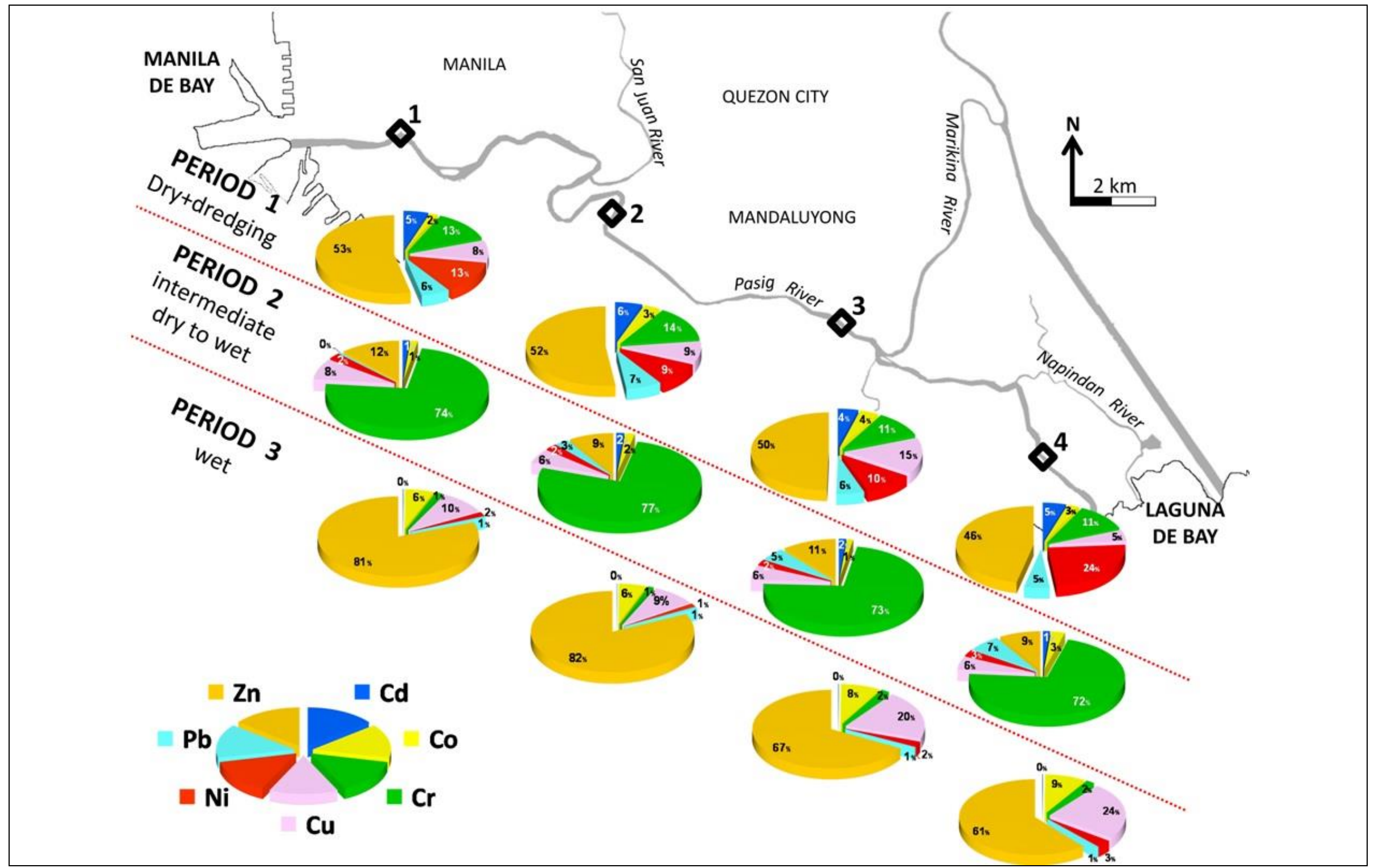

Fig. 3 Spatio-temporal variation of the trace metals among period 


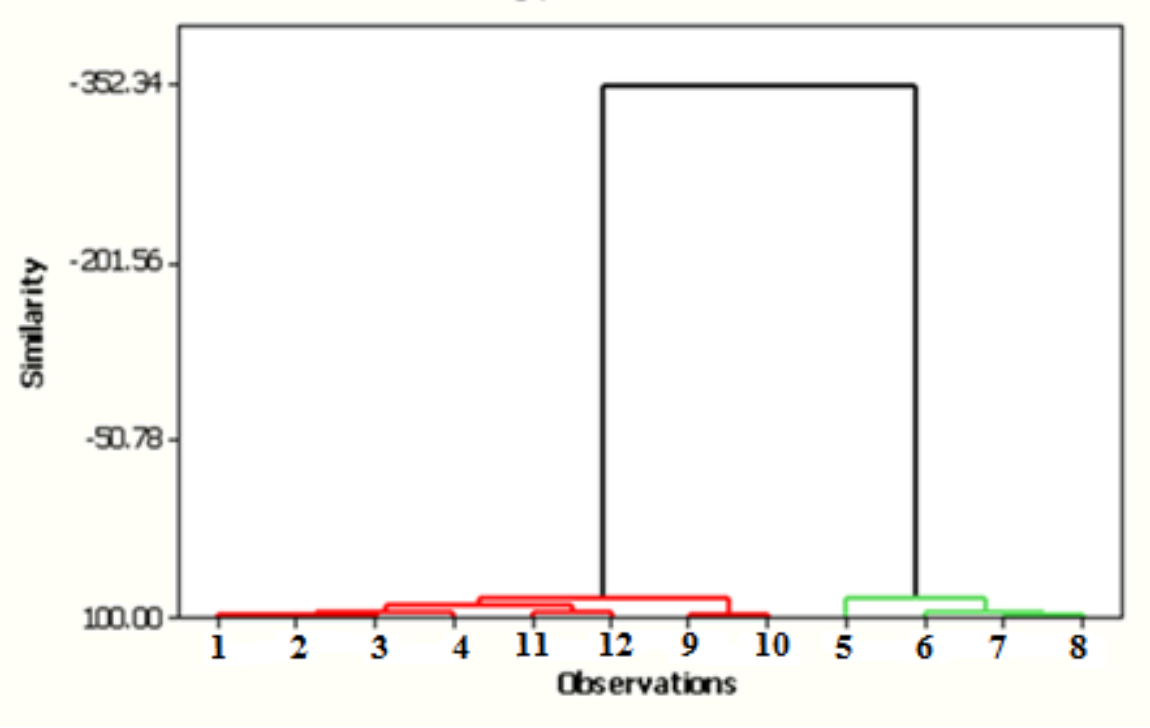

\section{1-Period 1 Point $1 \quad 9$-Period 3 Point $1 \quad 5$-Period 2 Point 1 \\ 2-Period 1 Point 2 10-Period 3 Point 2 6-Period 2 Point 2 \\ 3-Period 1 Point 3 11-Period 3 Point $3 \quad$ 7-Period 2 Point 3 \\ 4-Period 1 Point 4 12-Period 3 Point 4 8-Period 2 Point 4}

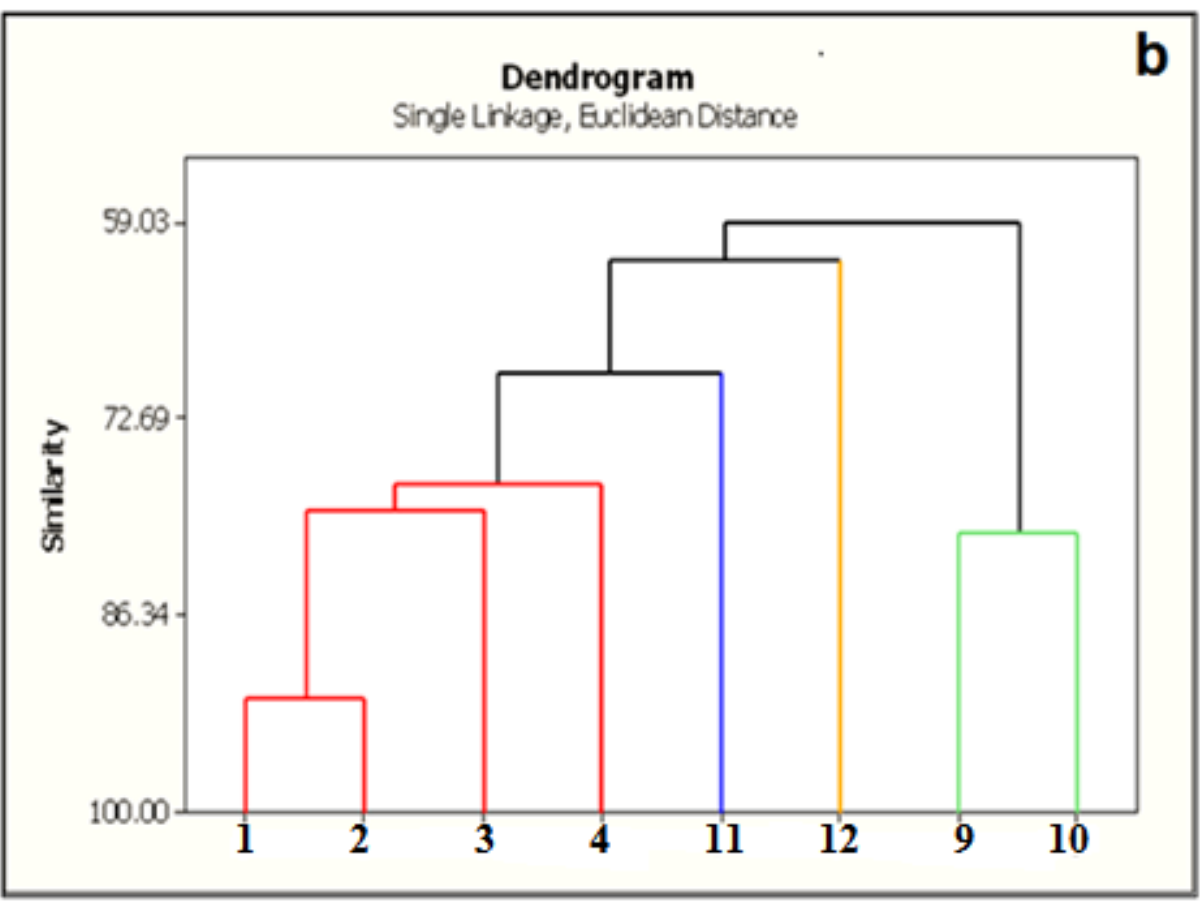

Fig. 4 Generated dendogram. Numbers indicate sampling regime (Period) and points. a: all the Periods and b: Periods 1 and 3 (Legend is provided in the middle) 


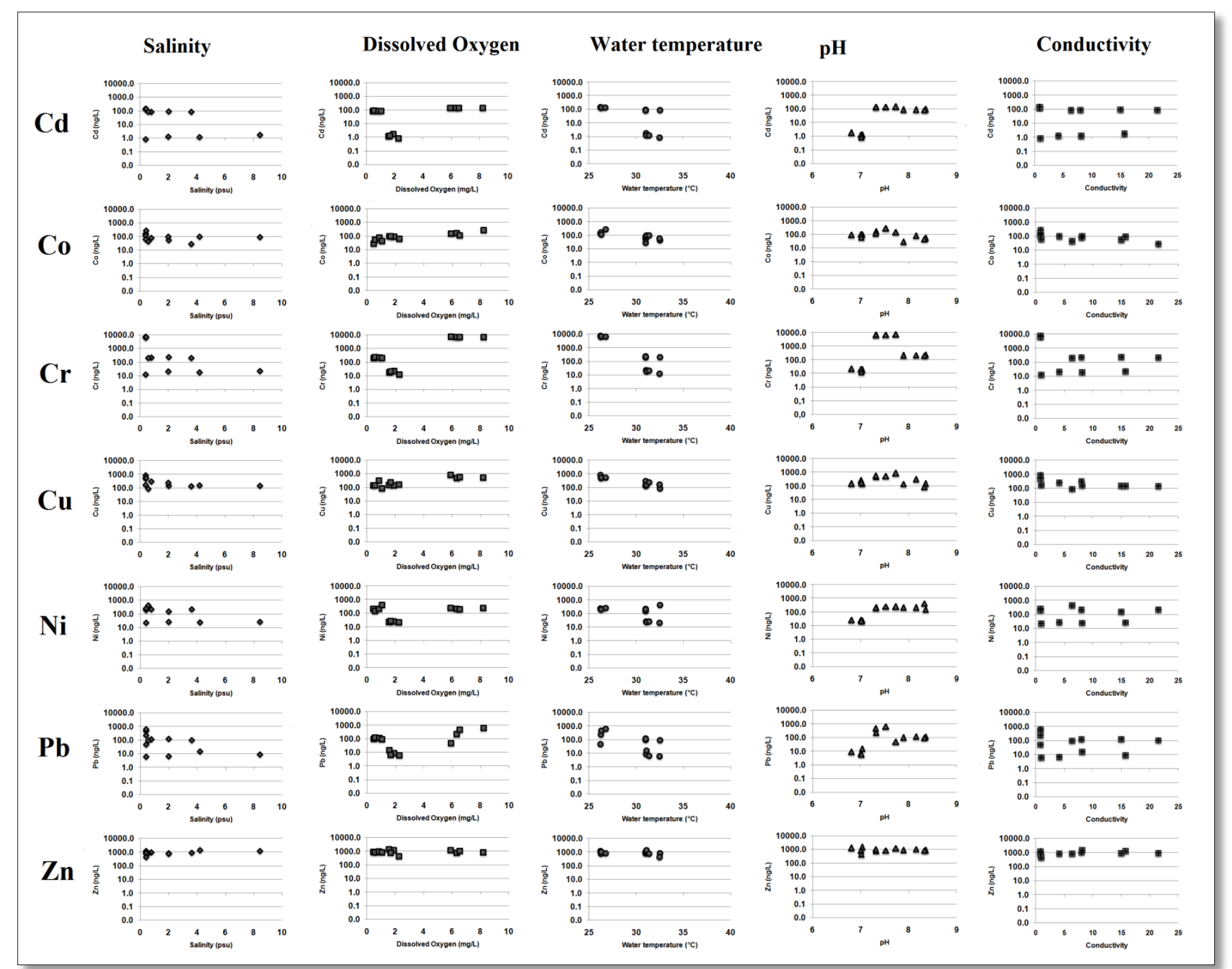

Fig. 5 Relationship of the physico-chemical parameters to the labile trace metal concentrations 
